\title{
ASSOCIATION OF SEROPREVALENCE AND RISK FACTORS IN LYME DISEASE
}

\author{
Andrea Bušová1, Erik Dorko, Eva Feketeová2, Kvetoslava Rimárová1, Jana Diabelková1, Tímea Rovenská1, \\ Tomáš Csank ${ }^{3}$ \\ 1Department of Public Health and Hygiene, Faculty of Medicine, Pavol Jozef Šafárik University in Košice, Košice, Slovak Republic \\ ${ }^{2}$ Department of Neurology, Faculty of Medicine, Pavol Jozef Šafárik University in Košice and Louis Pasteur University Hospital, Košice, Slovak \\ Republic \\ ${ }^{3}$ Department of Microbiology and Immunology, University of Veterinary Medicine and Pharmacy, Košice, Slovak Republic
}

\section{SUMMARY}

Objective: The aim of the presented cross-sectional seroepidemiological study was to determine the current presence of antibodies against B. burgdorferi s.l. in the groups of Slovak population, and to identify potential risk factors to Lyme borreliosis.

Methods: A group of 261 adults (patients from the Neurological Clinic with possible symptoms of LB and healthy persons with possible working exposure to tick bite: gardeners and soldiers working in afforested areas) were examined in order to assess the seroprevalence of anti-Borrelia antibodies. Sera were screened by commercial enzyme-linked immunosorbent assay (ELISA). The respondents completed questionnaires with general demographic, epidemiological and clinical data.

Results: We detected $17.2 \%$ presence of positive $\lg \mathrm{G}$ and $5.7 \%$ presence of positive $\operatorname{lgM}$ antibodies in all investigated groups. Our results confirmed that the following risk factors such as age and gender are significantly associated with the presence of positive specific antibodies against investigated disease.

Conclusion: The results of seroprevalence obtained in the present study confirm the possibility of infection with $B$. burgdorferi among respondents exposed to contact with ticks.

Key words: Lyme borreliosis, risk factor, seroprevalence

Address for correspondence: E. Dorko, Department of Public Health and Hygiene, Faculty of Medicine, Pavol Jozef Šafárik University in Košice, Šrobárova 2, 04180 Košice, Slovak Republic. E-mail: erik.dorko@upjs.sk

https://doi.org/10.21101/cejph.a5274

\section{INTRODUCTION}

Lyme borreliosis (LB) belong to the most current antropozoonosis in Europe and North America territory. Disease mostly occurs in countries of Middle and East Europe than in West region (1). Despite of fact that symptoms are well known, the origin of the pathogen was identified in early eighties of twentieth century and it's a complex of bacteria from the row of Spirochetales also shown as species group of Borrelia burgdorferi sensu lato (2).

Approximately 11 genotypes were strictly bound on Europe and Asia region $(3,4)$. Major human based pathogens in the Europe region are those three subspecies: $B$. burgdorferi sensu stricto, B. afzelii, B. garinii (1). B. valaisiana, B. lusitaniae can also be the originator of disease but only in rare occasions. However in the territory of North America the lead pathogens are nominotypical subspecies of $B$. burgdorferi sensu stricto, which suggest the introduction of borrelias from Europe to American continent (5). Transfer of borrelias is caused predominantly by ticks of the Ixodes ricinus genus and Argas genus $(6,7)$.

There is an increased incidence of LB in most European countries (2). Cases of increased morbidity are multi-aspect and concern not only the etiological factors alone, but also the spirochetes vector and reservoirs. Another mentioned factor contributing to an increase in morbidity due to borreliosis also increased popularity of active leisure and tourism, often associated with the penetration of ecosystems which have not been previously visited (1).

Early diagnostics and immediate onset of treatment is the most crucial for successful treatment of LB. At present there is no available vaccine against $L B$ in Europe that can guarantee required protection (8). In consideration that there is no vaccine against LB in Europe yet, the only form of protection before the disease is to prevent the tick bite. Prevention is crucial predominantly in endemic areas. Rate of risk depends on the length of exposure, therefore is significantly higher risk for permanent stays in nature especially for foresters, hunters, but also for occasional visitors to nature in terms of tourism, vacations etc. Increased risk of acquiring LB is also associated with work exposure especially in group of people working in endemic afforested areas (9).

Main aim of the work is to detect the LB seroprevalence in selected risk groups of population and to determine the association with the risk factors. 


\section{MATERIALS AND METHODS}

\section{Study Design}

Study design: cross-sectional study. Approval of the study protocol was received by the Ethics Committee of the University Hospital of Košice and signed informed consents were obtained from all the participants.

\section{Data Collection}

The serum samples used in this study were collected from 261 adults (126 examined at the Department of Neurology with possible symptoms of LB and 135 persons with possible working exposure to tick bite: gardeners and soldiers working in afforested areas) during the period from July 2013 to July 2016 (Table 1). Before data and blood sample collection informed consent was obtained from each examined person.

\section{Serum Samples}

The serum was obtained by the centrifugation $(2,500 \mathrm{rpm} / 10 \mathrm{~min})$ and preserved at $-80{ }^{\circ} \mathrm{C}$ until serological testing. The sera were processed in the Laboratory of the Department of Microbiology and Immunology of the University of Veterinary Medicine and Pharmacy in Košice.

\section{Questionnaire}

The questionnaires will reveal relationships between disease, positive laboratory samples and clinical symptoms. The questionnaire contained:

1. Demographic data: gender, age, residence.

2. Epidemiological data: tick bite, contact with animals, and frequent outdoor activities such as gardening, walking in nature, hunting and fishing

\section{Laboratory Analysis}

Sera were examined for the presence of specific anti-IgM and anti-IgG antibodies to B. burgdorferi (s.l.) with the use of the commercial ELISA test Borrelia burgdorferi IgG/IgM ELISA (recombinant), NovaLisa ${ }^{\mathrm{TM}}$, Germany. Borrelia burgdorferi IgG contains the following recombinant epitopes OspC of the phylum B31 (B. sensu stricto), 20047 and T25 (B. garinii), $\mathrm{p} 100$ and p18 of the phylum PKo (B. afzelii) and p41i of the phylum PBi (B. garinii). Borrelia burgdorferi IgM contains the following recombinant epitopes OspC of the phylum PKo (B. afzelii) and 20047 (B. garinii) and p41i of the phylum PBi

Table 1. Characteristics of the study group $(N=261)$

\begin{tabular}{|l|l|c|c|c|}
\hline & & $\begin{array}{c}\text { Male } \\
\mathbf{n}(\%)\end{array}$ & $\begin{array}{c}\text { Female } \\
\mathbf{n}(\%)\end{array}$ & $\begin{array}{c}\text { Total } \\
\mathbf{n}(\%)\end{array}$ \\
\hline Patients & $\begin{array}{l}\text { from the neurological } \\
\text { clinic }\end{array}$ & $64(50.8)$ & $62(49.2)$ & $126(100.0)$ \\
\hline \multirow{2}{*}{ Exposed } & soldiers & $91(88.3)$ & $12(11.7)$ & $103(100.0)$ \\
\cline { 2 - 5 } & gardeners & $19(59.4)$ & $13(40.6)$ & $32(100.0)$ \\
\hline
\end{tabular}

(B. garinii). The test procedure was performed according to the manufacturer's instructions and the optical density was measured with a spectrophotometer at $450 \mathrm{~nm}$ using an ELISA reader (Synergy HT BioTek). The results were calculated in NTU/ml (NovaTecUnits).

Results equal to $11 \mathrm{NTU} / \mathrm{ml}$ and above were considered as positive, those between 9 and $10 \mathrm{NTU} / \mathrm{ml}$ were considered as borderline, and those below $9 \mathrm{NTU} / \mathrm{ml}$ were considered as negative.

\section{Statistical Analysis}

Data acquired by the questionnaires and by laboratory tests were processed by use of IBM SPSS 21.0 statistical program. Demographic data were interpreted by descriptive statistics as averages with standard deviations and as percentages for categorical variables. To compare the difference in the occurrence of risk factors among selected file group we used the chi-square test. During the analysis we used logistic regression to interpret the influence between selected variables. For depended variable, we used seroprevalence of $\mathrm{IgG} / \mathrm{IgM}$ antibodies. For independent variable we used gender, age, residence, gardening, walking in nature, hunting, fishing, contact with animals and tick bite. Considered value for statistical significance was $\mathrm{p}<0.05$.

\section{RESULTS}

\section{File Characteristics}

Cross-sectional study contained 261 sera, from those 126 sera were obtained on UNLP Neurological Clinic in Košice with possible LB symptoms and 135 sera were obtained from people with possible work exposure to tick bite (gardeners and soldiers) in afforested area.

In the whole file men represented $66.7 \%(\mathrm{n}=174)$ with average age 43.42 (SD 16.48) years and women represented 33.3\% $(n=87)$ with average age 50.9 (SD 18.35) years. City as residence, had been reported in $57.9 \%(n=150)$ and countryside $42.1 \%(n=109)$ among all respondents (Table 2).

In file of patients men represented $50.8 \%(n=64)$ with average age 57.81 (SD 15.73) and women represented $49.2 \%(n=62)$ with average age 56.28 (SD 16.94) years. City residents was $75 \%(\mathrm{n}=93)$ and $25 \%(\mathrm{n}=31)$ residents lived in countryside (Table 2).

In file that consisted people with work exposure we have recorded $81.5 \%(\mathrm{n}=110)$ men with average age 35.31 (SD 10.17) years and $18.5 \%(n=25)$ women with average age $37.76($ SD 14.9) years. City as main residence has stated $42.2 \%(\mathrm{n}=57)$ persons and $57.8 \%(n=78)$ persons were living in countryside (Table 2$)$.

\section{Serology Results of IgG and IgM Antibodies}

Table 3 shows seroprevalence divided by individual files. From total number of 261 sera $17.2 \%(n=45)$ were considered positive of $\operatorname{IgG}$ and positive values of $\operatorname{IgM}$ were found in $5.7 \%$ $(\mathrm{n}=15)$ persons.

Borderline values of $\operatorname{IgG}$ were found in $1.9 \%(\mathrm{n}=5)$ and $\operatorname{IgM}$ antigens were found in $4.2 \%(n=11)$ of persons. 
Table 2. General characteristics of examined subjects $(N=261)$

\begin{tabular}{|c|c|c|c|c|c|c|c|c|}
\hline & & & \multicolumn{2}{|c|}{ Male } & \multicolumn{2}{|c|}{ Female } & \multicolumn{2}{|c|}{ Total } \\
\hline & & & $\mathrm{n}$ & $\%$ & $\mathrm{n}$ & $\%$ & $\mathrm{n}$ & $\%$ \\
\hline \multirow{4}{*}{ Patients } & \multicolumn{2}{|c|}{ Age - Mean (SD) } & - & $57.81(15.73)$ & - & $56.28(16.94)$ & - & $57.05(16.29)$ \\
\hline & \multirow{2}{*}{ Residence } & urban & 48 & 76.2 & 45 & 73.8 & 93 & 75.0 \\
\hline & & rural & 15 & 23.8 & 16 & 26.2 & 31 & 25.0 \\
\hline & \multicolumn{2}{|c|}{ Total number } & 64 & 50.8 & 62 & 49.2 & 126 & 100 \\
\hline \multirow{4}{*}{ Exposed } & \multicolumn{2}{|c|}{ Age - Mean (SD) } & - & $35.31(10.17)$ & - & $37.76(14.90)$ & - & $35.76(11.17)$ \\
\hline & \multirow{2}{*}{ Residence } & urban & 51 & 46.4 & 6 & 24.0 & 57 & 42.2 \\
\hline & & rural & 59 & 53.6 & 19 & 76.0 & 78 & 57.8 \\
\hline & \multicolumn{2}{|c|}{ Total number } & 110 & 81.5 & 25 & 18.5 & 135 & 100.0 \\
\hline \multirow{4}{*}{ Total } & \multicolumn{2}{|c|}{ Age - Mean (SD) } & - & $43.42(16.48)$ & - & 50.9 (18.35) & - & $45.91(17.45)$ \\
\hline & \multirow{2}{*}{ Residence } & urban & 99 & 57.2 & 51 & 59.3 & 150 & 57.9 \\
\hline & & rural & 74 & 42.8 & 35 & 40.7 & 109 & 42.1 \\
\hline & \multicolumn{2}{|c|}{ Total number } & 174 & 66.7 & 87 & 33.3 & 261 & 100.0 \\
\hline
\end{tabular}

Table 3. Results of serology of $\lg G / \operatorname{lgM}$ antibodies against B. burgdorferi s.I. by ELISA (N=261)

\begin{tabular}{|l|l|c|c|c|c|}
\hline \multirow{2}{*}{$\begin{array}{l}\text { Investigated } \\
\text { groups }\end{array}$} & \multirow{2}{*}{ Value } & \multicolumn{2}{|c|}{ IgG } & \multicolumn{2}{|c|}{ IgM } \\
\cline { 3 - 6 } & & $\mathbf{n}$ & $\%$ & $\mathbf{n}$ & $\%$ \\
\hline \multirow{4}{*}{ Patients } & Negative & 100 & 79.4 & 114 & 90.5 \\
\cline { 2 - 6 } & Positive & 24 & 19.0 & 7 & 5.6 \\
\cline { 2 - 6 } & Borderline & 2 & 1.6 & 5 & 4.0 \\
\cline { 2 - 6 } & Total & 126 & 100.0 & 126 & 100.0 \\
\hline \multirow{4}{*}{ Exposed } & Negative & 111 & 82.2 & 121 & 89.6 \\
\cline { 2 - 6 } & Positive & 21 & 15.6 & 8 & 5.9 \\
\cline { 2 - 6 } & Borderline & 3 & 2.2 & 6 & 4.4 \\
\cline { 2 - 6 } & Total & 135 & 100.0 & 135 & 100.0 \\
\hline \multirow{5}{*}{ Total } & Negative & 211 & 80.8 & 235 & 90.0 \\
\cline { 2 - 6 } & Positive & 45 & 17.2 & 15 & 5.7 \\
\cline { 2 - 6 } & Borderline & 5 & 1.9 & 11 & 4.2 \\
\cline { 2 - 6 } & Total & 261 & 100.0 & 261 & 100.0 \\
\hline
\end{tabular}

ELISA - enzyme-linked immunosorbent assay

Negative values for $\operatorname{IgG}$ antigens were recorded in $80.8 \%$ $(\mathrm{n}=211)$ and IgM antigens were found in $90.0 \%(\mathrm{n}=235)$ of the probands sample (Table 3).

From total number of 126 examined sera in patient population we did detect positive values of $\operatorname{IgG}$ antibodies in $19 \%$ $(\mathrm{n}=24)$, borderline were $1.6 \%(\mathrm{n}=2)$ and negative values were present in $79.4 \%(n=100)$ of persons. Positive values of $\operatorname{IgM}$ antibodies were found in $5.6 \%(n=7)$, borderline were $4 \%(n=5)$ and negative values were present in $90.5 \%(\mathrm{n}=114)$ of participants (Table 3).

Individuals exposed to tick bite with total count of 135 probands had positive values for IgG recorded in $15.6 \%(\mathrm{n}=21)$, borderline were $2.2 \%(n=3)$ and $82.2 \%(n=111)$ were negative.

Seropositivity of IgM antibodies was recorded in $5.9 \%$ $(\mathrm{n}=8)$, borderline values were $4.4 \%(\mathrm{n}=6)$ and negative values were found in $89.6 \%(\mathrm{n}=121)$ of participants (Table 3$)$.

\section{Frequency of Leisure Activities and Risk Factors}

In addition to the above mentioned characteristics we examine leisure activities as potential risk factor of LB. We were interested in gardening activity which was represented in $70.3 \%$ of respondents in researched file. Touristic represented $39.8 \%$, hunting $7.7 \%$, fishing $10.4 \%$, contact with animal $48.4 \%$. Contact tick bite was reported in $70.9 \%$ of respondents (Table 4 ).

\section{Association of IgG and IgM Antibodies Presence with Gender, Age and Residence}

In whole file we have recorded slightly increased seroprevalence of $\mathrm{IgG}$ in the group of women in comparison to men $(\mathrm{OR}=1.04$, 95\% CI $=0.54-1.99$ ) (Table 5). In the exposed file we have confirmed statistically significant effect of gender on IgM antigens class level. Women had $(\mathrm{OR}=4.03,95 \% \mathrm{CI}=1.25-12.93)$ higher presence probability of IgM class antigens than men (Table 6).

In patients file we have found that age had raised the amount of $\mathrm{IgG}$ antibodies which shows statistical significance $(\mathrm{OR}=1.04$, $95 \% \mathrm{CI}=1.01-1.08)$. Same results were shown in the total file $(\mathrm{OR}=1.02,95 \% \mathrm{CI}=1.00-1.04)$ (Table 5).

\section{Association of IgG and IgM Antibodies Presence with External Activities}

By given parameters (gardening, tourism, hunting, and fishing) we did not record any statistically significant effect on seroprevalence of IgG and IgM class antibodies (Table 5, 6).

\section{Association of IgG and IgM Antibodies Presence with Animal Contact Associated to Tick Bite}

Contact with animals was not a significant factor of higher IgG $(\mathrm{OR}=1.03,95 \% \mathrm{CI}=0.55-1.91)$, nor $\operatorname{IgM}(\mathrm{OR}=1.51,95 \% \mathrm{CI}$ $=0.67-3.43)$ seroprevalence as well as tick bite to levels of $\mathrm{IgG}$ $(\mathrm{OR}=1.53,95 \% \mathrm{CI}=0.73-3.17)$ and $\operatorname{IgM}(\mathrm{OR}=0.91,95 \% \mathrm{CI}$ $=0.38-2.20)$ class antibodies in the total set of representatives (Table 5, 6). 
Table 4. Demographic and exposure characteristics of the investigated group ( $N=261)$

\begin{tabular}{|c|c|c|c|c|c|c|c|c|}
\hline \multirow{3}{*}{\multicolumn{2}{|c|}{ Risk factors / characteristics }} & \multicolumn{6}{|c|}{ Investigated groups } & \multirow{3}{*}{$\begin{array}{c}\chi^{2} \text { test } \\
p \text {-value }\end{array}$} \\
\hline & & \multicolumn{2}{|c|}{ Patients } & \multicolumn{2}{|c|}{ Exposed } & \multicolumn{2}{|c|}{ Total } & \\
\hline & & $\mathrm{n}$ & $\%$ & $\mathrm{n}$ & $\%$ & $\mathrm{n}$ & $\%$ & \\
\hline \multirow{2}{*}{ Gardening } & yes & 74 & 59.2 & 108 & 80.6 & 182 & 70.3 & \multirow{2}{*}{$<0.001^{* * *}$} \\
\hline & no & 51 & 40.8 & 26 & 19.4 & 77 & 29.7 & \\
\hline \multirow{2}{*}{ Nature walks } & yes & 23 & 18.4 & 80 & 59.7 & 103 & 39.8 & \multirow{2}{*}{$<0.001^{* * *}$} \\
\hline & no & 102 & 81.6 & 54 & 40.3 & 156 & 60.2 & \\
\hline \multirow{2}{*}{ Hunting } & yes & 2 & 1.6 & 18 & 13.4 & 20 & 7.7 & \multirow{2}{*}{$<0.001^{* * *}$} \\
\hline & no & 123 & 98.4 & 116 & 86.6 & 239 & 92.3 & \\
\hline \multirow{2}{*}{ Fishing } & yes & 7 & 5.6 & 20 & 14.9 & 27 & 10.4 & \multirow{2}{*}{$0.02^{*}$} \\
\hline & no & 118 & 94.4 & 114 & 85.1 & 232 & 89.6 & \\
\hline \multirow{2}{*}{$\begin{array}{l}\text { Contact with } \\
\text { animals }\end{array}$} & yes & 51 & 41.5 & 74 & 54.8 & 125 & 48.4 & \multirow{2}{*}{$0.04^{*}$} \\
\hline & no & 72 & 58.5 & 61 & 45.2 & 133 & 51.6 & \\
\hline \multirow{2}{*}{ Tick bite } & yes & 69 & 55.6 & 114 & 85.1 & 183 & 70.9 & \multirow{2}{*}{$<0.001^{\text {*** }}$} \\
\hline & no & 55 & 44.4 & 20 & 14.9 & 75 & 29.1 & \\
\hline
\end{tabular}

$\chi^{2}$ test - chi-square test, ${ }^{*} p<0.05,{ }^{* *} p<0.01,{ }^{* * *} p<0.001$

Table 5. Associations between risk factors and seroprevalence of IgG antibodies against B. burgdorferi detected by ELISA

\begin{tabular}{|l|c|c|c|}
\hline \multirow{2}{*}{ Risk factors } & \multicolumn{2}{|c|}{ Seroprevalence IgG } \\
\cline { 2 - 4 } & $\begin{array}{c}\text { Patients } \\
\text { OR (95\% Cl) }\end{array}$ & $\begin{array}{c}\text { Exposed } \\
\text { OR (95\% Cl) }\end{array}$ & $\begin{array}{c}\text { Total } \\
\text { OR (95\% Cl) }\end{array}$ \\
\hline Gender woman/man (ref.) & $0.86(0.36-2.04)$ & $1.20(0.40-3.59)$ & $1.04(0.54-1.99)$ \\
\hline Age $\uparrow$ & $1.04(1.01-1.08)^{*}$ & $1.01(0.97-1.05)$ & $1.02(1.00-1.04)^{* *}$ \\
\hline Residence rural/urban (ref.) & $0.88(0.32-2.43)$ & $1.58(0.63-4.00)$ & $0.78(0.41-1.51)$ \\
\hline Gardening yes/no (ref.) & $0.76(0.32-1.81)$ & $0.90(0.30-2.68)$ & $1.12(0.60-2.10)$ \\
\hline Nature walks yes/no (ref.) & $1.45(0.51-4.14)$ & $1.15(0.47-2.87)$ & $2.45(0.93-6.52)$ \\
\hline Hunting yes/no (ref.) & $3.92(0.24-64.88)$ & $2.72(0.91-8.19)$ & $0.70(0.23-2.13)$ \\
\hline Fishing yes/no (ref.) & - & $1.18(0.36-3.89)$ & $1.03(0.55-1.91)$ \\
\hline Contact with animals yes/no (ref.) & $1.14(0.47-2.77)$ & $0.97(0.40-2.35)$ & $1.53(0.73-3.17)$ \\
\hline Tick bite yes/no (ref.) & $1.67(0.68-4.11)$ & $2.03(0.44-9.44)$ & \\
\hline
\end{tabular}

Logistic regression, OR - odds ratio, $\mathrm{Cl}-$ confidence interval, ${ }^{*} \mathrm{p}<0.05,{ }^{* *} \mathrm{p}<0.01$

Table 6. Associations between risk factors and seroprevalence of IgM antibodies against B. burgdorferi detected by ELISA

\begin{tabular}{|l|c|c|c|}
\hline \multirow{2}{*}{ Risk factors } & \multicolumn{2}{|c|}{ Seroprevalence IgM } \\
\cline { 2 - 4 } & $\begin{array}{c}\text { Patients } \\
\text { OR (95\% Cl) }\end{array}$ & $\begin{array}{c}\text { Exposed } \\
\text { OR (95\% Cl) }\end{array}$ & $\begin{array}{c}\text { Total } \\
\text { OR (95\% CI) }\end{array}$ \\
\hline Gender woman/man (ref.) & $0.71(0.21-2.38)$ & $4.03(1.25-12.93)^{*}$ & $1.53(0.67-3.50)$ \\
\hline Age $\uparrow$ & $0.97(0.93-1.00)$ & $1.04(1.00-1.08)$ & $1.00(0.97-1.02)$ \\
\hline Residence rural/urban (ref.) & $1.00(0.25-3.96)$ & $1.36(0.43-4.29)$ & $0.95(0.39-2.28)$ \\
\hline Gardening yes/no (ref.) & $0.66(0.20-2.18)$ & $1.50(0.31-7.16)$ & $0.94(0.41-2.16$ \\
\hline Nature walks yes/no (ref.) & $0.88(0.18-4.30)$ & $0.89(0.29-2.72)$ & $1.66(0.45-6.08)$ \\
\hline Hunting yes/no (ref.) & $10.18(0.60-174.30)$ & $1.08(0.22-5.30)$ & - \\
\hline Fishing yes/no (ref.) & - & - & $1.51(0.67-3.43)$ \\
\hline Contact with animals yes/no (ref.) & $3.16(0.90-11.15)$ & $0.81(0.27-2.44)$ & $0.910 .38-2.20)$ \\
\hline Tick bite yes/no (ref.) & $0.78(0.24-2.56)$ & $1.06(0.22-5.13)$ & \\
\hline
\end{tabular}




\section{DISCUSSION}

Lyme Borreliosis is a multisystem disease that is currently the largest anthroposis on the European continent. To determine the final diagnosis beside the clinical picture, the laboratory tests based on determination of specific antibodies are needed to be performed (5).

The aim of the seroepidemiological study was to determine the seroprevalence of LB and to point out the possible risk factors associated with the disease in selected population groups. The investigated group consisted of participants with work activities in nature and patients from the neurology ward.

Many studies conducted on a group of healthy people in Europe show the presence of antibodies against $B$. burgdorferi between $4.3 \%$ and $19.7 \%$ (11-13).

In our study we have recorded the presence of specific IgG antibodies in $17.6 \%(\mathrm{n}=45)$ and $5.7 \%(\mathrm{n}=15)$ of IgM antibodies against $B$. burgdorferi throughout examined file by ELISA test. Similar results were found in the first studies conducted in Poland that have confirmed the presence of antibodies by ELISA method in $11-13 \%$ (14).

Lower seroprevalence of $\operatorname{IgG}$ antibodies was shown in studies conducted in north Peking - 5.1\% (15). Cross-sectional study conducted from 2008 to 2011 in Deutschland showed - 9.4\% (16). Study from Italy conducted on group of blood donors showed 4.9\% $(\mathrm{n}=365)(17)$ and results from Romania showed $4.3 \%(\mathrm{n}=1,598)(18)$.

Higher risk of acquiring LB arises with work exposure. Threatened are predominantly people living or working in endemic afforested areas (9). Despite this fact, we have recorded higher percentage of positivity $(19.0 \%)$ in group of patients than in the group of exposed IgG antibodies.

In the group of exposed probands who conducted their work tasks such as recreational activities in nature, we recorded $15.6 \%$ seroprevalence for IgG antibodies and 5.9\% for IgM. Higher percentages of antibodies were recorded in the study of farmers and forest workers in Turkey. The ELISA test confirmed 10.9\% seroprevalence (18). Seropositive in France was 14.3\% (19), Spain $23.8 \%$ (20), Hungary 37\% (21), Sweden 5.3\% (22), Croatia 4.7\% (23), in Poland 23.68-40.7\% (26).

In whole research group we have recorded by use of logistic regression slightly higher seroprevalence of IgG antibodies in male group compared to female group $(\mathrm{OR}=1.04$, $95 \% \mathrm{CI}=0.54-1.99$ ), but without statistical significance. In general it is well known that men often conducte work activities in nature. Higher seroprevalence in male group had been confirmed by Wilking et al. (16). On the other hand, the statistically significant influence of gender on the level of IgG class antibodies was confirmed in the set of exposed patients. Female group shows $(\mathrm{OR}=4.03,95 \% \mathrm{CI}=1.25-12.93)$ higher presence probability of IgM class antibodies than in male group.

Higher seroprevalence of $\operatorname{IgG}$ antibodies was found in a group of people living in rural areas than in the city but without statistical significance. Significantly higher OR seroprevalence was confirmed in relation to the growing age of respondents $(\mathrm{OR}=1.02,95 \% \mathrm{CI}=1.00-1.04, \mathrm{p}<0.01)$ who were expected to work and perform recreational activities in tick biotope. A similar result is shown by the study performed by Zajac et al., where significant differences in the age of the serous response were found. Many studies confirm the relationship with the growing age (25).

Most of $B$. burgdorferi infections are the result of exposure to infected ticks during activities related to outdoor work or outdoor maintenance, recreational and leisure activities (17).

In our study, we examined up to $70.9 \%$ of the tick bite with a higher percentage in the group of exposed individuals. The presence of antibodies was higher in the group with a positive history of tick bite, but the association of seropositivity as a result of tick bite was not statistically significant.

The relevance of the relationship between seroprevalence and work or contact with pet animals has not been confirmed. A study by Dou et al. showed the same results as our study (15). Unlike the results in Europe, pet animals were not risk factors for becoming a seropositive disease for Lyme disease. Activities such as gardening, hunting, walking in nature, and fishing in this study appeared to be an insignificant risk factor $(p>0.05)$. Study by Werner et al. confirmed the link between the occurrence of antibodies and external activities (22).

Lyme disease has been licensed in Europe in which dominated another pathogenic Borrelia, prevention should be based on non-specific measures to reduce the risk of tick bite and appropriate bite management. Preventive measures include: avoiding exposures by limiting activities in nature with the occurrence of ticks, using repellent sprays on clothing and exposed skin - is effective against tick bites and other vectors such as tabanid flies and mosquitoes; adequately cover clothing and frequent skin check for timely detection and correct removal of ticks (17).

\section{CONCLUSION}

The results of seroprevalence obtained in the current study confirm the possibility of B. burgdorferi infection among respondents exposed to the tick. Our results have confirmed that the following risk factors, such as age and gender, are significantly associated with the presence of positive specific antibodies against the disease being investigated. The results confirmed higher seropositivity in patients than in exposed individuals. This study shows that it is important for public health authorities to improve their understanding and ability to monitor key risk factors known to have an impact on the adoption of proposed preventive measures in target population. Preventive measures are relatively simple and not very costly. Information on the risks of these diseases should be improved.

\section{Acknowledgements}

This work was supported by Grants VEGA No. 1/0198/13, 1/0011/14 of the Ministry of Education, Science, Research and Sport of the Slovak Republic and project VVGS - 3/GSD/2016. We thank also Directory board of Louis Pasteur University Hospital in Košice for assistance with organization of samples collection at the hospital wards.

\section{Conflict of Interests}

None declared 


\section{REFERENCES}

1. Cook MJ. Lyme borreliosis: a review of data on transmission time after tick attachment. Int J Gen Med. 2015;8:1-8.

2. Embers E M, Narasimhan S. Vaccination against Lyme disease: past, present, and future. Front Cell Infect Microbiol. 2013;3:6. doi: 10.3389/ fcimb.2013.00006.

3. Bhide MR, Trávniček M. Borreliosis - Lyme disease. In: Dorko E, Baranová Z, Dubinský P, Pistl J, et al. Bacterial, viral, parasitic and mycotic zoonoses: bacterial and mycotic zoonoses. Košice: Equilibria; 2009. p. 26-43.

4. Rudenko N, Golovchenko M, Gruphoffer L, Oliver JH Jr. Updates on Borrelia burgdorferi sensu lato complex with respect to public health. Ticks Tick Borne Dis. 2011 Sep;2(3):123-8.

5. Křupka M, Strojil J, Raška M. Current options of diagnostics, treatment and prevention of Lyme borreliosis. Prakt Lek. 2014;4(2-3):79-82.

6. Gray J, Stanek G, Kundi M, Kocianova E. Dimensions of engorging Ixodes ricinus as a measure of feeding duration. Int J Med Microbiol. 2005;295(8):567-72.

7. Mayne PJ. Emerging incidence of Lyme borreliosis, babesiosis, bar tonellosis, and granulocytic ehrlichiosis in Australia. Int J Gen Med. 2011;4:845-52.

8. Schuijt TJ, Hovius JW, van der Poll T, van Dam AP, Fikrig E. Lyme borreliosis vaccination: the facts, the challenge, the future. Trends Parasitol. 2011 Jan;27(1):40-7.

9. Rizzoli A, Hauffe HC, Carpi G, Vourc'h GI, Neteler M, Rosà R. Lyme borreliosis in Europe. Euro Surveill. 2011;16(27):pii=19906.

10. Zając V, Pinkas J, Wójcik-Fatla A, Dutkiewicz J, Owoc A, Bojar I. Prevalence of serological response to Borrelia burgdorferi in farmers from eastern and central Poland. Eur J Clin Microbiol Infect Dis. 2017;36(3):437-46

11. Carlsson SA, Granlund H, Nyman D, Wahlberg P. IgG seroprevalence of Lyme borreliosis in the population of the Aland Islands in Finland. Scand J Infect Dis. 1998;30(5):501-3.

12. Chmielewski T, Tylewska-Wierzbanowska S. Prevalence of Borrelia burgdorferi antibodies in healthy population in Poland. Przegl Epidemiol. 2002;56(1):33-8. (In Polish.)

13. Hristea A, Hristescu S, Ciufecu C, Vasile A. Seroprevalence of Borrelia burgdorferi in Romania. Eur J Epidemiol. 2001;17(9):891-6.

14. Pańczuk A, Kozioł-Montewka M, Tokarska-Rodak M. Exposure to ticks and seroprevalence of Borrelia burgdorferi among a healthy young population living in the area of southern Podlasie, Poland. Ann Agric Environ Med. 2014;(21)3:512-7.
15. Dou X, Lyu Y, Jiang Y, Tian L, Li X, Lin C, et al. Seroprevalence of Lyme disease and associated risk factors in rural population of Beijing. Int J Clin Exp Med. 2015;8(5):7995-9.

16. Wilking H, Fingerle V, Klier C, Thamm M, Stark K. Antibodies against Borrelia burgdorferi sensu lato among adults, Germany, 2008 - 2011. Emerg Infect Dis. 2015 Jan;21(1):107-10

17. Tomao P, Ciceroni L, D’Ovidio MC, De Rosa M, Vonesch N, Iavicoli S, et al. Prevalence and incidence of antibodies to Borrelia burgdorferi and to tick-borne encephalitis virus in agricultural and forestry workers from Tuscany, Italy. Eur J Clin Microbiol Infect Dis. 2005 Jul;24(7):457-63.

18. Kaya AD, Parlak AH, Ozturk CE, Behcet M. Seroprevalence of Borrelia burgdorferi infection among forestry workers and farmers in Duzce, north-western Turkey. New Microbiol. 2008;31(2):203-9.

19. Christiann F, Rayet P, Patey O, Ngueodjibaye DB, Theron-le Gargasson JF, Lafaix C. Lyme borreliosis in central France: A sero-epidemiologic examination involving hunters. Europ J Epidemiol. 1997 Oct;13(7):855.

20. Rojko T, Ruzic-Sabjic E, Strle F, Lotric-Furlan S. Prevalence and incidence of Lyme borreliosis among Slovene forestry workers during period of tick activity. Wien Klin Wochenschr. 2005;117(5-6):219-25.

21. Lakos A, Igari Z, Solymosi N. Recent lesson from a clinical and seroepidemiological survey: low positive predictive value of Borrelia burgdorferi antibody testing in a high risk population. Ad Med Sci. 2012;57(2):356-63

22. Werner M, Nordin P, Arnholm B, Elgefors B, Krantz I. Borrelia burgdorferi antibodies in outdoor and indoor workers in south-west Sweden. Scand J Infect Dis. 2001;33(2):128-31.

23. Poljak I, Troselj-Vukic B, Miletic B, Morovic M, Ruzic-Sabljic E, Vucemilovic A, et al. Low sero-prevalence of Lyme borreliosis in the forested mountainous area of Gorski Kotar, Croatia. Croat Med J. 2000;41(4):433-6.

24. Chmielewska-Badora J. Seroepidemiologic study on Lyme borreliosis in the Lublin region. Ann Agric Environ Med. 1998;5(2):183-6.

25. Cisak E, Chmielewska-Badora J, Zwoliński J, Wójcik-Fatla A, Polak J, Dutkiewicz J. Risk of tick-borne bacterial diseases among workers of Roztocze National Park (south-eastern Poland). Ann Agric Environ Med. 2005;12(1):127-32.

26. Pancewicz S A, Januszkiewicz A, Hermanowska-Szpakowicz T. Detection of antibodies of Borrelia burgdorferi among inhabitants of northeastern Poland. Przegl Epidemiol. 1996;50(4):375-81. (In Polish.)

Received December 5, 2017 Accepted in revised form October 1, 2018 